\title{
Characteristics of Clay Soft Soil in the Mekong Delta of Vietnam and Improvement Result with Cement
}

\author{
Binh Vu Ngoc ${ }^{1, *}$ \\ Hydraulic Construction Institute, Vietnam Academy for Water Resources, Vietnam \\ Correspondence: Binhdkt@gmail.com
}

\begin{abstract}
Received: The results of research on the characteristics of soft clay soils distributed in some provinces of 11 August 2021 the Mekong Delta show that most of the soils are contaminated with easily soluble salts, Accepted: 28 October 2021 containing organic matter, $\mathrm{pH}<7$. Sandy clay, clay in An Giang, and clay mud in Tien Giang are less acidic, not salty, and contamination of salts in the form of sulfate- chloride. Clay mud in Hau Giang is less acidic, less salt, and contamination of salts in the form of chloride-sulfate.

Published: Clay mud in Bac Lieu and Ca Mau are lots of salty soil, contaminated with chloride of salts. Peat soil in Kien Giang is strongly acidic, not salty, contaminated with sulfate -chloride. All of them have a large compression coefficient, small load capacity, therefore they should be reinforced when construction works. Unconfined compressive strength of reinforced soils with cement showed that sandy clay in An Giang is the best, and then is soft clay in An Giang and clay mud in Tien Giang, Hau Giang, Bạc Lieu, and Ca Mau. Peat soil in Kien Giang has a low strength at different contents and days of age (with a concents $400 \mathrm{~kg} / \mathrm{m}^{3}$ at 91 days has unconfined compressive strength $\mathrm{q}_{\mathrm{u}}=201 \mathrm{kPa}$ ), only 12.8 to $23.0 \%$ compared to the soil elsewhere. The curing time process samples show that the compressive strength of the peat soil mixed cement is increased initially, then they were decreased over a period of 28 days.
\end{abstract}

Keywords: Soft soil; Characteristics of soil; Organic matter; Reinforced soil; Salt contamination; Unconfined compressive strength

\section{Introduction}

The Mekong Delta of Vietnam is formed from young deposits of Holocene age (Q2) with many different origins such as a mixture of alluvial-marine (am), alluvial-bog (ab), marine (m). Sediments originated from am distributed right on the surface; the thickness is from 10 to over 20 meters. Mainly composed of clay mud, silty clay mud, sandy clay mud, some places are contaminated with salt, alum, and organic. Therefore, they can be classified as special soils. Most of the constructions there have foundation treatment solutions. In which, the improvement of soft soil with cement has been applied and brought a certain effect. However, soft soil clays have complex characteristics and compositions so combining with cement will have different results. Thus, the study of improving some soft soils with Portland Cement Blended (PCB) in the Mekong Delta has a directional significance in using cement for foundation treatment. Any type of soil, with the exception of highly organic soils or some highly plastic clays may be stabilized with cement (Bell, 1993; Awadh, and Al-Owaidi, 2020; Awadh, and Al-Owaidi, 2021). Clay soils with liquid limits exceeding $45 \%$ and plasticity indices above $18 \%$ are not usually

DOI: $\underline{10.46717 / i g j .55 .1 A .5 M s-2022-01-24}$ 
subjected to cement stabilization (Croft, 1968). The chemical and mineralogical composition also greatly affects the hydration and hardening of cement-reinforced soils. Kaolinite and illite have little or no effect on the hydration and hardening process of cement stabilization (Bell, 1976; Awad and Awadh, 2020); however, expansive clay minerals have a strong influence on the hardening ability of cement soil depending on their activity level. Illite and chlorite may be having an effect on the same montmorillonite. Gibbsite strongly reacts with lime which slows down the bonding process of lateritic clays. The montmorillonite in the clay reacts with the lime in the cement, reducing the $\mathrm{pH}$ of the hydration process leading to a decrease in the strength of the reinforcing soil compared to the non-expansive clays (Bell, 1976). Organic matter in the soil adsorbs calcium ions slowing the hydration of cement. The amount of salt in the soil, especially is sulfate salt can be prevented or slowed the hydration of cement. The soils containing more than 2 percent organic material and $\mathrm{pH}<5$ is less economically efficient (Anon, 1990). When the soil has contained SO3 over 0.2 percent and SO4 over 0.5 percent or the amount of $\mathrm{SO} 3$ in groundwater exceeds 300 milligram/liter, there is a risk of damaging the cement soil mixture (Sherwood, 1957). This paper has presented the results of a study on composition characteristics, physicomechanical properties of soft clay soils in the Mekong Delta, and their improvement with cement. The map of the study area is shown in Fig. 1.

\section{Materials and Methods}

Clay soft soils are obtained from some different locations in the Mekong Delta (Fig.1); the thickness of them is from 10 to 20 meters; the main composition is clay mud, clay, sandy clay soft state. Soil samples were taken in the undisturbed state, maintained in saturated conditions, and tested with physical and mechanical properties, compositions: mineral, chemistry, and cation exchange capacity. The cement used in the study is Tay Do (PCB40), a popular cement in Mekong Delta. Cement sample was tested for its chemical composition before being mixed with the soil. The soil samples are tested in the laboratory and site according to ASTM and BS EN ISO 17892 standards. Standards are shown in Table 1. The reinforced soil sample is made according to Japanese JGS 0821-2000 and Chinese DBJ08-40-94 standards; the sample is height twice the diameter $(\mathrm{h}=100 \mathrm{~mm}, \mathrm{D}=50 \mathrm{~mm})$. Soil samples mixed cement with the contents $250,300,350,400 \mathrm{~kg} / \mathrm{m}^{3}$, ratio of water/cement is $1(\mathrm{w} / \mathrm{c}=1)$ and were cured under saturated conditions after that reinforced samples are tested unconfined compression strength according to ASTM D2166 at 7, 14, 28, 56, 91 and 180 age days (Fig.2).

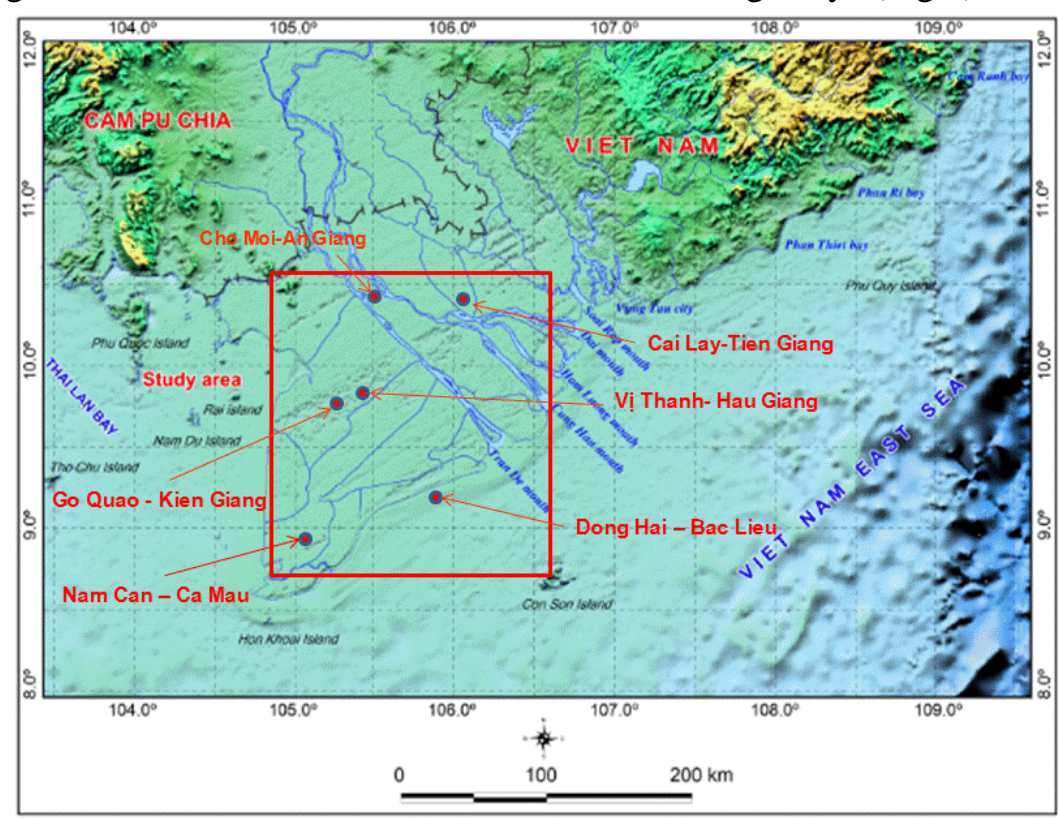

Fig.1. Location map of study area in the Mekong Delta, Vietnam 


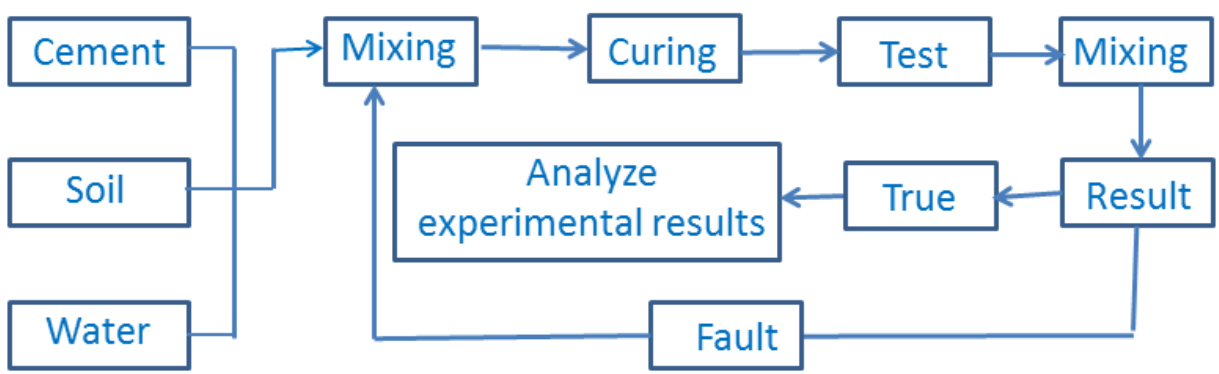

Fig. 2. The process of making, curing and, testing the samples

Table 1. Physical and mechanical properties of the studied soils

\begin{tabular}{lccc}
\hline Properties & Standards & Properties & Standards \\
Sand grain size $(\%)$ & $\mathrm{D} 6913$ & Internal friction angle $\varphi($ độ $)$ & BS EN ISO 17892-10 \\
Silt grain size $(\%)$ & $\mathrm{D} 7928-17$ & Cohesion unit $(\mathrm{c}, \mathrm{kPa})$ & $\mathrm{BS}$ EN ISO 17892-10 \\
Clay grain size $(\%)$ & $\mathrm{D} 7928-17$ & Compressibility coefficient a $1-2\left(\mathrm{kPa}^{-1}\right)$ & $\mathrm{D} 2435$ \\
Natural moisture $\mathrm{W}(\%)$ & $\mathrm{D} 2216$ & $\mathrm{Su}(\mathrm{kPa})$ & $\mathrm{D} 2573$ \\
Wet density $\gamma_{\mathrm{w}}\left(\mathrm{kN} / \mathrm{m}^{3}\right)$ & $\mathrm{D} 7263$ & $\mathrm{Su}(\mathrm{kPa})$ & $\mathrm{D} 2573$ \\
Specific Gravity $\rho$ & $\mathrm{D} 854$ & Coefficient of permeability, $\mathrm{k}(\mathrm{cm} / \mathrm{s})$ & $\mathrm{BS} 17892-11$ \\
$\left(\mathrm{kN} / \mathrm{m}^{3}\right)$ & $\mathrm{D} 4318$ & SPT experiment, $\mathrm{N}_{30}$ & $\mathrm{D} 1586$ \\
Liquid limit $\mathrm{W}_{\mathrm{L}}(\%)$ & $\mathrm{D} 4318$ & & \\
Plastic limit $\mathrm{W}_{\mathrm{P}}(\%)$ & & & \\
\hline
\end{tabular}

Table 2. Distribution characteristics of soft soil in some research locations

\begin{tabular}{|c|c|c|c|c|c|c|}
\hline $\begin{array}{l}\text { Distribution } \\
\text { characteristics }\end{array}$ & $\begin{array}{l}\text { Cho Moi Dist, An } \\
\text { Giang province }\end{array}$ & $\begin{array}{c}\text { Cai Lay Dist, } \\
\text { Tien Giang } \\
\text { province } \\
\end{array}$ & $\begin{array}{c}\text { Go Quao Dist - } \\
\text { Kien Giang } \\
\text { province }\end{array}$ & $\begin{array}{c}\text { Vi Thanh Dist - } \\
\text { Hau Giang } \\
\text { province }\end{array}$ & $\begin{array}{c}\text { Dong Hai Dist, } \\
\text { Bac Lieu } \\
\text { province }\end{array}$ & $\begin{array}{c}\text { Cai Nuoc Dist, } \\
\text { Ca Mau } \\
\text { province } \\
\end{array}$ \\
\hline Embankment & $\begin{array}{l}\text { Stiff state clay, } \\
\text { thickness from } 2.7 \text { to } \\
3.4 \text { meters }\end{array}$ & $\begin{array}{c}\text { Embankment } \\
\text { thickness from } \\
2.7 \text { to } 3.4 \text { meters }\end{array}$ & $\begin{array}{c}\text { Embankment } \\
\text { thickness } 0.8 \\
\text { meter }\end{array}$ & $\begin{array}{l}\text { Embankment } \\
\text { thickness from } \\
0.5 \text { to } 0.8 \text { meter }\end{array}$ & $\begin{array}{c}\text { Embankment } \\
\text { thickness } 1.5 \\
\text { meters }\end{array}$ & $\begin{array}{c}\text { Embankment } \\
\text { thickness from } \\
0.8 \text { to } 1.0 \text { meters }\end{array}$ \\
\hline Soft soils research & $\begin{array}{c}\text { Soft state Silty clay } \\
\text { mixed sandy clay, } \\
\text { thickness from } 7 \text { to } 10 \\
\text { meters } \\
\text { Soft to very soft clay, } \\
\text { thickness from } 12 \text { to } \\
24.2 \text { meters }\end{array}$ & $\begin{array}{l}\text { Clay mud mixed } \\
\text { organic, } \\
\text { thickness from } \\
8.2 \text { to } 9.7 \text { meters }\end{array}$ & $\begin{array}{l}\text { Peat, thickness } \\
\text { from } 10 \text { to } 12.5 \\
\text { meters }\end{array}$ & $\begin{array}{l}\text { Clay mud, } \\
\text { thickness from } 10 \\
\text { to } 15 \text { meters }\end{array}$ & $\begin{array}{c}\text { Clay mud, } \\
\text { thickness from } 8 \\
\text { to } 12 \text { meters } \\
\text { Soft clay, } \\
\text { thickness from } \\
7.5 \text { to } 9.7 \text { meters }\end{array}$ & $\begin{array}{l}\text { Clay mud mixed } \\
\text { organic, } \\
\text { thickness from } 2 \\
\text { to } 11 \text { meters } \\
\text { Clay mud, } \\
\text { thickness from } \\
7.5 \text { to } 17 \text { meters }\end{array}$ \\
\hline
\end{tabular}

\section{Results and Discussion}

\subsection{Results of soil characteristics}

\subsubsection{Mineral composition of the soil}

Soil samples were tested to determine mineral composition by differential thermal method on STA - PT 1600 and diffraction radiation (D8 - Advance machine). Experimental results are presented in Table 3. The results of studying the mineral composition of soft clay soils in the Mekong Delta showed that the clay mineral group with high dispersion was quite large. It is including illite (from $13 \%$ with peat soil in Kien Giang to 24\% with soft clay in An Giang and clay mud in Ca Mau), kaolinite (from $7 \%$ with peat soil in Kien Giang to $21 \%$ with clay mud in Ca Mau), chlorite (from $5 \%$ with peat soil in Kien Giang to $8 \%$ with clay mud in soils elsewhere). Thus, they have strongly contaminated with alum. Goethite mineral in clay mud is usually $2-7 \%$, particularly peat soil in Kien Giang (14-16\%); the 
presence of goethite makes the soil contain iron. Montmorillonite ranged from 2 to 6 percent except for sandy clay in An Giang, which was not present. The minerals montmorillonite, illite, chlorite are factors that are detrimental to the soil improvement with cement. Organic soil in Kien Giang is smaller quartz minerals than clayey soils elsewhere, while goethite is larger than and contains minerals such as pyrite, pyrophyllite and gypsum.

Table 3. Mineralogy composition of soil in the research area

\begin{tabular}{|c|c|c|c|c|c|c|c|}
\hline Location & $\begin{array}{r}\text { Cho } \\
\text { An Gia }\end{array}$ & $\begin{array}{l}\text { Dist } \\
\text { rovince }\end{array}$ & $\begin{array}{c}\text { Cai Lay } \\
\text { Dist, Tien } \\
\text { Giang } \\
\text { province }\end{array}$ & $\begin{array}{c}\text { Go Quao } \\
\text { Dist, Kien } \\
\text { Giang } \\
\text { province }\end{array}$ & $\begin{array}{c}\text { Vi Thanh } \\
\text { Dist, Hau } \\
\text { Giang } \\
\text { province }\end{array}$ & $\begin{array}{c}\text { Dong Hai } \\
\text { Dist, Bac } \\
\text { Lieu } \\
\text { province }\end{array}$ & $\begin{array}{c}\text { Cai Nuoc } \\
\text { Dist. Ca } \\
\text { Mau } \\
\text { province }\end{array}$ \\
\hline Minerals & $\begin{array}{l}\text { Soft sandy } \\
\text { clay }\end{array}$ & Soft clay & Clay mud & Peat & Clay mud & Clay mud & Clay mud \\
\hline Montmorillonite (\%) & small & $3-5$ & $3-5$ & 5 & $2-4$ & $2-4$ & $4-6$ \\
\hline Illite $-\mathrm{KAl}_{2}\left[\mathrm{AlSi}_{3} \mathrm{O}_{10}\right](\mathrm{OH})_{2}(\%)$ & 14 & $22-24$ & $18-21$ & 13 & 19 & $21-23$ & $20-24$ \\
\hline Kaolinite $-\mathrm{Al}_{2}\left[\mathrm{Si}_{2} \mathrm{O}_{5}\right](\mathrm{OH})_{4}(\%)$ & 8 & $10-13$ & $16-18$ & 7 & 16 & $13-18$ & $19-21$ \\
\hline Chlorite $-\mathrm{Mg}_{2} \mathrm{Al}_{3}\left[\mathrm{AlSi}_{3} \mathrm{O}_{10}\right](\mathrm{OH})_{8}(\%)$ & 7 & 8 & 7 & 5 & 8 & $7-8$ & $7-8$ \\
\hline Quartz $-\mathrm{SiO}_{2}(\%)$ & $47-49$ & $36-38$ & $36-40$ & $23-25$ & $39-41$ & $36-38$ & $29-33$ \\
\hline Felspate $-\mathrm{K}_{0.5} \mathrm{Na}_{0.5} \mathrm{AlSi}_{3} \mathrm{O}_{8}(\%)$ & $4-6$ & $5-7$ & $3-6$ & $3-5$ & $4-6$ & $4-8$ & $4-7$ \\
\hline Goethite $-\mathrm{Fe}_{2} \mathrm{O}_{3} \cdot \mathrm{H}_{2} \mathrm{O}(\%)$ & 3 & $2-4$ & 5 & $14-16$ & 7 & $5-6$ & $5-7$ \\
\hline Amphibole $(\%)$ & small & & small & small & small & small & small \\
\hline Pyrite $-\mathrm{FeS}_{2}(\%)$ & & & & $5-7$ & & & \\
\hline Pyrophyllite $-\mathrm{Al}\left[\mathrm{Si}_{2} \mathrm{O}_{5}\right](\mathrm{OH})(\%)$ & & & & 4 & & & \\
\hline Gypsum - $\mathrm{CaSO}_{4}$ & & & & 15 & & & \\
\hline Other minerals & & Pyrite & Pyrite & Gibbsite & Siderite & $\begin{array}{c}\text { Gibbsite, } \\
\text { Calcite }\end{array}$ & $\begin{array}{l}\text { Bormit, } \\
\text { Calcite }\end{array}$ \\
\hline
\end{tabular}

\subsubsection{Chemical composition of soil}

Testing of the chemical composition of soil samples was performed on analyzer Plasma emission spectrometer - IRIS INTREPID. Experimental results are presented in Table 4. The results of soil chemical composition analysis showed that: Clays types in An Giang, Tien Giang, Hau Giang, Bac Lieu and $\mathrm{Ca} \mathrm{Mau}$ have similar oxide content values: $\mathrm{SiO}_{2}$ ranges from $56.37 \%$ to $68.44 \% ; \mathrm{Al}_{2} \mathrm{O}_{3}$ ranges from $14.09 \%$ to $18.76 \% ; \mathrm{Fe}_{2} \mathrm{O}_{3}$ ranges from $3.09 \%$ to $5.82 \%$; $\mathrm{FeO}$ ranges from $1.46 \%$ to $2.55 \%$. Peat soil in Kien Giang has content oxides are smaller than elsewhere soils, specifically: $\mathrm{SiO}_{2}=27.87 \%, \mathrm{Al}_{2} \mathrm{O}_{3}=$ $9.23 \% ; \mathrm{FeO}=0.15 \%, \mathrm{TiO}_{2}=0.37 \%$, while contents $\mathrm{Fe}_{2} \mathrm{O}_{3}=6.67 \%$ and $\mathrm{SO}_{3}=10.8 \%$ are greater. The total content of the soluble salt oxides $\left(\mathrm{Na}_{2} \mathrm{O}\right.$ and $\left.\mathrm{K}_{2} \mathrm{O}\right)$ ranges from $2.02 \%$ to $4.53 \%$. The above results show that soil shows signs of acidity and salt contamination, peat soil in Kieng Giang is strongly acidic. The loss shows that most of the soil studied above are mixed organic soils (content loss $<10 \%$ at $450^{\circ} \mathrm{C}$ ). Particularly, soil in Kien Giang is quite high (loss $44.23 \%$ ).

Table 4. Chemical composition of soils in the research

\begin{tabular}{|c|c|c|c|c|c|c|c|}
\hline \multirow{2}{*}{$\begin{array}{l}\text { Location } \\
\text { Chemical composition (\%) }\end{array}$} & \multicolumn{2}{|c|}{$\begin{array}{l}\text { Cho Moi distric - An } \\
\text { Giang province }\end{array}$} & \multirow{2}{*}{$\begin{array}{c}\text { Cai Lay } \\
\text { Dist, Tien } \\
\text { Giang } \\
\text { province } \\
\text { Clay mud }\end{array}$} & \multirow{2}{*}{$\begin{array}{c}\text { Go Quao } \\
\text { Dist, Kien } \\
\text { Giang } \\
\text { province } \\
\text { Peat }\end{array}$} & \multirow{2}{*}{$\begin{array}{l}\text { Vi Thanh } \\
\text { Dist, Hau } \\
\text { Giang } \\
\text { province } \\
\text { Clay mud }\end{array}$} & \multirow{2}{*}{$\begin{array}{c}\text { Dong Hai } \\
\text { Dist, Bac } \\
\text { Lieu } \\
\text { province }\end{array}$} & \multirow{2}{*}{ 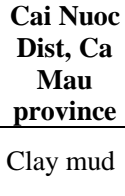 } \\
\hline & $\begin{array}{l}\text { Soft sandy } \\
\text { clay }\end{array}$ & Soft clay & & & & & \\
\hline $\mathrm{SiO}_{2}$ & 68.44 & 59.54 & 57.18 & 27.87 & 59.93 & 59.65 & 57.60 \\
\hline $\mathrm{TiO}_{2}$ & 0.80 & 0.87 & 0.93 & 0.37 & 1.08 & 0.90 & 0.81 \\
\hline $\mathrm{Al}_{2} \mathrm{O}_{3}$ & 14.09 & 18.76 & 17.6 & 9.23 & 17.52 & 16.78 & 16.92 \\
\hline $\mathrm{Fe}_{2} \mathrm{O}_{3}$ & 3.09 & 3.49 & 4.89 & 6.67 & 3.90 & 5.12 & 4.24 \\
\hline $\mathrm{FeO}$ & 2.11 & 2.34 & 2.55 & 0.15 & 1.65 & 1.74 & 1.52 \\
\hline $\mathrm{MnO}$ & 0.09 & 0.10 & 0.11 & 0.12 & 0.16 & 0.12 & 0.10 \\
\hline $\mathrm{CaO}$ & 0.47 & 0.47 & 0.47 & 1.30 & 0.77 & 0.93 & 1.72 \\
\hline $\mathrm{MgO}$ & 1.26 & 1.62 & 1.33 & 1.38 & 1.92 & 1.74 & 2.35 \\
\hline $\mathrm{K}_{2} \mathrm{O}$ & 2.14 & 2.73 & 2.83 & 1.75 & 2.96 & 2.57 & 3.02 \\
\hline $\mathrm{Na}_{2} \mathrm{O}$ & 0.41 & 0.46 & 0.37 & 0.27 & 0.77 & 1.05 & 1.51 \\
\hline $\mathrm{P}_{2} \mathrm{O}_{5}$ & 0.08 & 0.11 & 0.86 & 0.11 & 0.20 & 1.11 & 0.24 \\
\hline $\mathrm{SO}_{3}$ & 0.95 & 1.13 & 1.91 & 10.80 & 1.20 & 0.53 & 1.72 \\
\hline Loss $\left(450^{\circ} \mathrm{C}\right)$ & 3.16 & 4.60 & 7.2 & 44.28 & 2.39 & 4.43 & 3.17 \\
\hline Loss $\left(900^{\circ} \mathrm{C}\right)$ & 6.78 & 9.04 & 11.37 & 50.05 & 8.00 & 9.23 & 9.50 \\
\hline
\end{tabular}




\subsubsection{The exchange capacity of soil}

The results of the soil exchange capacity test are presented in Table 5. The experimental results showed:

- The exchange capacity of the soil varies from $3.60 \mathrm{mg} / 100 \mathrm{~g}$ (clay mud in Tien Giang) to 15.0 $\mathrm{mg} / 100 \mathrm{~g}$ (clay mud in Hau Giang) and $15.6 \mathrm{mg} / 100 \mathrm{~g}$ (peat in Kien Giang), with elsewhere exchange capacity soil from 6.08 to $8.84 \mathrm{mg} / 100 \mathrm{~g}$.

- The dominant $\mathrm{Fe}^{2+}$ cation ranges from $153.5 \mathrm{mg} / 100 \mathrm{~g}$ (peat soil in Kien Giang) to $1733.06 \mathrm{mg}$ /100 g (clay in An Giang); soils in Hau Giang, Bac Lieu, and Ca Mau have a much higher content of anions $\mathrm{Cl}^{-}$(from 464.4 to $934.74 \mathrm{mg} / 100 \mathrm{~g}$ ) than soils in An Giang, Tien Giang and Kien Giang (only from 13.47 to $68.06 \mathrm{mg} / 100 \mathrm{~g}$ ). However, the soil in Ca Mau is lower content of anion $\mathrm{SO}_{4}{ }^{2-}$ than in other regions.

- Total dissolved salt shows that soil in Hau Giang, Bac Lieu, and Ca Mau have quite large total dissolved salt ranges from 2,194 to $3,624 \%$, while the soils in the rest areas range from 0.346 to $0.758 \%$.

- The $\mathrm{pH}$ of soils in the research area is smaller than 7; it belongs to an acid environment, especially peat soil in Kien Giang has $\mathrm{pH}=4.1$.

- According to the classification of salinity based on the content ratio of $\mathrm{Cl}^{-}(\% \mathrm{o})$ anion has in the soil shows that soil in $\mathrm{Ca} \mathrm{Mau}$, Bac Lieu are from salty to very salty $\left(\mathrm{Cl}^{-}>5\right)$, soil in Hau Giang is medium sanliness $\left(\mathrm{Cl}^{-}=3.0-5.0\right)$, Tien Giang, An Giang and Kiên Giang is not salty $\left(\mathrm{Cl}^{-}<1.5\right)$.

- According to the classification of the authors V.M. Bezruk, Yu.L. Motulev, A.L.Grot, A.I.Znamenxki, M.F. Ieruxalimyxkaya (Cited in Toan Do Minh., 2013, p.103), based on the form of salt contamination determined by the anion ratio of $\mathrm{Cl}^{-} / \mathrm{SO}_{4}{ }^{2-}$ shows that the soil in $\mathrm{Ca} \mathrm{Mau}$ and Bac Lieu are contaminated with salt in the form of chloride $\left(\mathrm{Cl}^{-} / \mathrm{SO}_{4}{ }^{2-}>2\right)$, soil in Hau Giang is contaminated with salt Chloride-Sulfate $\left(\mathrm{Cl}^{-} / \mathrm{SO}_{4}{ }^{2-}=1.466\right)$, soil in Kien Giang, Tien Giang and clay in An Giang are contaminated with sulfate-chloride salt.

Also, according to the above authors too, the assessment of classification belongs to the degree of salt contamination, based on the average total salt content of soluble salts, calculated by $\%$ of dry weight soil, shows that soil in Ca Mau, Bac Lieu and Hau Giang are salted contamination; soil in Tien Giang, An Giang and Kien Giang are less contaminated with salt.

Table 5. Cation exchange capacity of the soil

\begin{tabular}{|c|c|c|c|c|c|c|c|c|}
\hline Location & & $\begin{array}{r}\text { Cho' Moi D } \\
\text { pr }\end{array}$ & $\begin{array}{l}\text { An Giang } \\
\text { ce }\end{array}$ & $\begin{array}{c}\text { Cai Lay } \\
\text { Dist, Tien } \\
\text { Giang } \\
\text { province }\end{array}$ & $\begin{array}{c}\text { Go Quao } \\
\text { Dist, Kien } \\
\text { Giang } \\
\text { province }\end{array}$ & $\begin{array}{c}\text { Vi Thanh } \\
\text { Dist, Hau } \\
\text { Giang } \\
\text { province }\end{array}$ & $\begin{array}{c}\text { Dong Hai } \\
\text { Dist, Bac } \\
\text { Lieu } \\
\text { province }\end{array}$ & $\begin{array}{c}\text { Cai Nuoc } \\
\text { Dist. Ca } \\
\text { Mau } \\
\text { province }\end{array}$ \\
\hline Properties & unit & sandy clay & Soft clay & Clay mud & Peat & Clay mud & Clay mud & Clay mud \\
\hline $\mathrm{pH}$ & & 5.8 & 5.7 & 5.6 & 4.1 & 6.2 & 6.3 & 6.7 \\
\hline $\begin{array}{l}\text { Total dissolved } \\
\text { salt }\end{array}$ & $\%$ & 0.346 & 0.525 & 0.543 & 0.758 & 2.298 & 3.624 & 2.194 \\
\hline $\mathrm{Fe}^{2+}$ & $\mathrm{mg} / 100 \mathrm{~g}$ & 207.18 & 1733.06 & 589.76 & 153.50 & 331.50 & 324.25 & 184.67 \\
\hline $\mathrm{Fe}^{3+}$ & $\mathrm{mg} / 100 \mathrm{~g}$ & 16.26 & 55.26 & 12.79 & 6.00 & 9.50 & 18.75 & 13.56 \\
\hline $\mathrm{Ca}^{2+}$ & $\mathrm{ldl} / 100 \mathrm{~g}$ & 6.04 & 5.36 & 7.70 & 1.02 & 6.80 & 7.0 & 0.54 \\
\hline $\mathrm{Mg}^{2+}$ & $\mathrm{ldl} / 100 \mathrm{~g}$ & 4.02 & 7.45 & 6.61 & 1.09 & 11.80 & 10.60 & 1.64 \\
\hline $\mathrm{Al}^{3+}$ & $\mathrm{ldl} / 100 \mathrm{~g}$ & 0.10 & 0.12 & 0.07 & 1.00 & 0.0 & 0.0 & 0.0 \\
\hline $\mathrm{Cl}^{-}$ & $\mathrm{mg} / 100 \mathrm{~g}$ & 13.47 & 68.06 & 15.07 & 25.26 & 464.4 & 857.89 & 934.74 \\
\hline $\mathrm{SO}_{4}{ }^{2-}$ & $\mathrm{mg} / 100 \mathrm{~g}$ & 188.52 & 78.36 & 75.37 & 308.20 & 168.37 & 131.63 & 16.65 \\
\hline $\mathrm{Na}^{+}$ & $\mathrm{ld} / 100 \mathrm{~g}$ & 1.67 & 2.12 & 1.33 & 0.68 & 15.22 & 17.74 & 16.19 \\
\hline $\mathrm{K}^{+}$ & $\mathrm{ldl} / 100 \mathrm{~g}$ & 0.30 & 0.78 & 0.30 & 0.47 & 1.08 & 1.40 & 1.06 \\
\hline CEC & $\mathrm{mg} / 100 \mathrm{~g}$ & 6.08 & 8.84 & 3.60 & 15.60 & 15.00 & 6.60 & 8.51 \\
\hline $\operatorname{sum} \mathrm{N}$ & $\%$ & 0.064 & 0.84 & 0.11 & 0.33 & 0.081 & 0.14 & 0.11 \\
\hline humus & $\%$ & 1.98 & 2.10 & 2.33 & 19.41 & 2.97 & 2.76 & 3.49 \\
\hline $\mathrm{Mn}$ & $\mathrm{mg} / \mathrm{kg}$ & 782 & 1204.0 & 661.0 & 2558.3 & 1213.8 & 663.5 & 612.87 \\
\hline
\end{tabular}




\subsubsection{Mechanical and physical properties of soil}

At the research positions, we have performed field tests such as vane and standard penetration tests. The testing of mechanical and physical properties in the laboratory is carried out according to ASTM and BS standards. The results are presented in Table 6. The experimental results of the soil's physical and mechanical properties show that the researched soils are all soft soil (silty clay and clay soft to very soft, clay mud, peat), with weak construction properties, large compression coefficients, small bearing capacity, large void coefficient, etc. When constructing works in there, we must be a solution to improve them or appropriate foundation treatment. From the physical and mechanical properties of the soil, we showed that the soil in An Giang is better than about ability to reinforced with cement because this area has a higher sand grains group than other soils, and soil in Kien Giang is the low efficiency of improving because in the soil was contained a lot of organic matter, very high natural moisture, and small wet density.

Table 6. Mechanical and physical properties of soil

\begin{tabular}{|c|c|c|c|c|c|c|c|c|}
\hline \multirow{2}{*}{$\begin{array}{l}\text { Location } \\
\text { Properties }\end{array}$} & \multirow[b]{2}{*}{ Unit } & \multicolumn{2}{|c|}{$\begin{array}{l}\text { Cho Moi Dist - An Giang } \\
\text { province }\end{array}$} & \multirow{2}{*}{$\begin{array}{c}\text { Cai Lay } \\
\text { Dist, Tien } \\
\text { Giang } \\
\text { province } \\
\text { Clay mud }\end{array}$} & \multirow{2}{*}{$\begin{array}{c}\text { Go Quao } \\
\begin{array}{c}\text { Dist, Kien } \\
\text { Giang } \\
\text { province }\end{array} \\
\text { Peat }\end{array}$} & \multirow{2}{*}{$\begin{array}{l}\text { Vi Thanh } \\
\text { Dist, Hau } \\
\text { Giang } \\
\text { province } \\
\text { Clay mud }\end{array}$} & \multirow{2}{*}{ 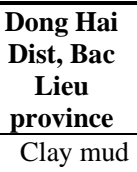 } & \multirow{2}{*}{$\begin{array}{c}\text { Cai Nuoc } \\
\text { Dist. Ca } \\
\text { Mau } \\
\text { province } \\
\text { Clay mud }\end{array}$} \\
\hline & & sandy clay & Soft clay & & & & & \\
\hline \multirow{3}{*}{ 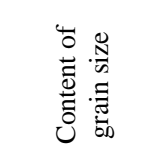 } & - Fine sand (\%) & 61.1 & 43.6 & 35.5 & 36,5 & 33.9 & 31.1 & 37.0 \\
\hline & - Silt (\%) & 22.5 & 21.1 & 24.0 & 45,2 & 19.3 & 27.8 & 20.4 \\
\hline & - Clay (\%) & 16.4 & 34.3 & 40.5 & 18,3 & 46.7 & 41.1 & 42.6 \\
\hline \multirow{7}{*}{ 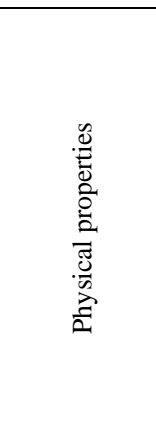 } & $\begin{array}{l}\text { Moisture content } \\
\mathrm{W}(\%)\end{array}$ & 39.5 & 50.7 & 66.5 & 285 & 93.5 & 58.6 & 76.6 \\
\hline & $\begin{array}{l}\text { Wet density } \gamma_{w} \\
\left(\mathrm{KN} / \mathrm{m}^{3}\right)\end{array}$ & 1.76 & 1.68 & 1.57 & 1.13 & 1.48 & 1.62 & 1.54 \\
\hline & $\begin{array}{l}\text { Dry density } \gamma_{c} \\
\left(\mathrm{KN} / \mathrm{m}^{3}\right)\end{array}$ & 1.26 & 1.12 & 0.94 & 0.29 & 0.76 & 1.02 & 0.87 \\
\hline & $\begin{array}{l}\text { Specific Gravity } \\
\gamma_{\mathrm{s}}\left(\mathrm{KN} / \mathrm{m}^{3}\right)\end{array}$ & 2.67 & 2.67 & 2.59 & 1.90 & 2.67 & 2.67 & 2.65 \\
\hline & $\begin{array}{l}\text { Satured Degree } \mathrm{G} \\
(\%)\end{array}$ & 94.0 & 97.2 & 98.5 & 98.6 & 99.9 & 97.1 & 99.3 \\
\hline & Porosity n (\%) & 52.9 & 58.2 & 63.6 & 84.6 & 71.5 & 61.74 & 67.2 \\
\hline & Void ratio $\varepsilon_{0}$ & 1.122 & 1.392 & 1.745 & 5.492 & 2.502 & 1.614 & 2.046 \\
\hline \multirow{3}{*}{. } & $\begin{array}{l}\text { Liquid limit LL } \\
(\%)\end{array}$ & 41.3 & 49.8 & 62.0 & 235.8 & 71.6 & 57.1 & 69.6 \\
\hline & $\begin{array}{l}\text { Plastic limit PL } \\
(\%)\end{array}$ & 27.7 & 30.5 & 34.6 & 171.6 & 38.0 & 33.3 & 38.0 \\
\hline & $\begin{array}{l}\text { Plastic Index PI } \\
(\%)\end{array}$ & 13.6 & 19.4 & 27.5 & 64.2 & 33.6 & 23.8 & 31.7 \\
\hline \multirow{3}{*}{ 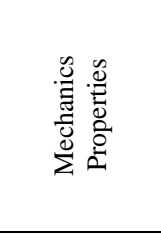 } & $\begin{array}{l}\text { Intinal Friction } \\
\text { Angle } \varphi \text { (độ) }\end{array}$ & $6^{\circ} 33^{\prime}$ & $4^{\circ} 19^{\prime}$ & $3^{\circ} 32^{\prime}$ & $2^{\circ} 04^{\prime}$ & $2^{\circ} 14^{\prime}$ & $3^{\circ} 07^{\prime}$ & $3^{\circ} 22^{\prime}$ \\
\hline & $\begin{array}{l}\text { Coshesion } \quad \mathrm{C} \\
(\mathrm{kPa})\end{array}$ & 6.96 & 5.59 & 3.73 & 1.47 & 2.06 & 3.33 & 4.02 \\
\hline & $\begin{array}{l}\text { Compression } \\
\text { coefience } \quad a_{1-2} \\
\left(\mathrm{kPa}^{-1}\right)\end{array}$ & 0.96 & 2.17 & 3.68 & 16.49 & 7.71 & 4.65 & 4.27 \\
\hline \multirow{2}{*}{ 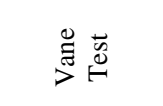 } & $\mathrm{Su}(\mathrm{kPa})$ & 20.10 & 21.57 & 17.36 & 10.10 & 14.32 & 15.30 & 15.89 \\
\hline & $\mathrm{Su}^{\prime}(\mathrm{kPa})$ & 4.12 & 3.53 & 3.92 & 3.24 & 3.33 & 3.53 & 4.90 \\
\hline Strain modulu & us Eo $(\mathrm{kPa})$ & 2647.8 & 1284.7 & 676.7 & 490.3 & 735.5 & 725.7 & 666.8 \\
\hline $\begin{array}{l}\text { Conventional } \\
(\mathrm{kPa})\end{array}$ & load capacity, Ro & 53.0 & 42.2 & 32.4 & 17.7 & 23.5 & 31.4 & 32.4 \\
\hline $\begin{array}{l}\text { Permeability } \\
(\mathrm{cm} / \mathrm{s})\end{array}$ & coefficient, $\quad \mathrm{K}$ & $2.61 \times 10^{-5}$ & $1.7 \times 10^{-5}$ & $5.21 \times 10^{-6}$ & $1.28 \times 10^{-5}$ & $2.12 \times 10^{-6}$ & $2.2 \times 10^{-6}$ & $5.16 \times 10^{-6}$ \\
\hline SPT test, $\mathrm{N}_{30}$ & & 2 & 2 & 2 & 1 & $1-2$ & $1-2$ & $1-2$ \\
\hline
\end{tabular}




\subsection{The Result of Research Improve Soft Soils with Cement}

\subsubsection{Chemical composition of cement}

Testing of the chemical composition of cement was performed on analyzer Plasma emission spectrometer - IRIS INTREPID. Experimental results are presented in Table 7.

Table 7. Chemical composition of studied cement

\begin{tabular}{|c|c|c|c|c|c|}
\hline Properties & Value (\%) & Properties & Value $(\%)$ & Properties & Value (\%) \\
\hline $\mathrm{SiO}_{2}$ & 21.71 & $\mathrm{MnO}$ & 0.07 & $\mathrm{P}_{2} \mathrm{O}_{5}$ & 0.15 \\
\hline $\mathrm{TiO}_{2}$ & 0.46 & $\mathrm{CaO}$ & 54.74 & $\mathrm{SO}_{3}$ & 2.25 \\
\hline $\mathrm{Al}_{2} \mathrm{O}_{3}$ & 5.27 & $\mathrm{MgO}$ & 2.91 & $\mathrm{Cr}_{2} \mathrm{O}_{3}$ & 0.01 \\
\hline $\mathrm{Fe}_{2} \mathrm{O}_{3}$ & 3.43 & $\mathrm{~K}_{2} \mathrm{O}$ & 1.23 & Fineness & 0.83 \\
\hline $\mathrm{FeO}$ & 0.56 & $\mathrm{Na}_{2} \mathrm{O}$ & 0.79 & Loss $\left(900^{\circ} \mathrm{C}\right)$ & 6.85 \\
\hline
\end{tabular}

\subsubsection{The result of research improves soft soil with cement}

Testing results of unconfined compressive strength of soils mixing cement samples with different contents and days of age are presented in Table 8 . The relationship between unconfined compressive strength with cement contents at different age days of soft soil in Mekong Delta is shown in Fig. 3.

Table 8. Unconfined compressive strength of soil mixing cement samples with different contents and days of age

\begin{tabular}{|c|c|c|c|c|c|c|c|}
\hline \multirow{2}{*}{ No. } & \multirow{2}{*}{$\begin{array}{c}\text { Contents } \\
\left(\mathbf{k g} / \mathbf{m}^{3}\right)\end{array}$} & \multicolumn{6}{|c|}{ Unconfined compressive strength $\left(q_{u}, k P a\right)$ curing time (days) } \\
\hline & & 7 & 14 & 28 & 56 & 91 & 180 \\
\hline 1 & SCAG - 250 & 478,6 & 521,0 & 589,3 & 798,3 & 1012,4 & 1035,3 \\
\hline 2 & CAG - 250 & 405,3 & 432,9 & 597,7 & 761,3 & 885,3 & 995,4 \\
\hline 3 & CMTG - 250 & 214,5 & 303,5 & 480,7 & 682,5 & 745,0 & 793,1 \\
\hline 4 & PKG - 250 & 93,2 & 229,4 & 188,0 & 152,5 & 148,3 & 101,6 \\
\hline 5 & CMHG -250 & 350,2 & 397,6 & 562,4 & 661,1 & 721,0 & 784,0 \\
\hline 6 & CMBL - 250 & 253,8 & 406,3 & 445,8 & 597,4 & 765,4 & 868,9 \\
\hline 7 & CMCM -250 & 212,0 & 392,5 & 415,2 & 575,0 & 624,8 & 791,6 \\
\hline 8 & SCAG - 300 & 518,8 & 611,1 & 789,8 & 881,5 & 1123,8 & 1204,3 \\
\hline 9 & CAG - 300 & 415,3 & 552,2 & 776,6 & 921,6 & 1000,3 & 1108,7 \\
\hline 10 & CMTG - 300 & 230,1 & 407,4 & 528,7 & 700,7 & 926,3 & 1023,8 \\
\hline 11 & PKG - 300 & 154,9 & 267,4 & 236,2 & 173,0 & 164,8 & 130,9 \\
\hline 12 & CMHG -300 & 359,5 & 412,4 & 636,1 & 692,8 & 747,4 & 809,0 \\
\hline 13 & CMBL - 300 & 333,3 & 444,0 & 562,6 & 684,1 & 841,3 & 944,3 \\
\hline 14 & CMCM -300 & 323,4 & 409,9 & 447,4 & 601,8 & 721,4 & 810,1 \\
\hline 15 & SCAG - 350 & 581,5 & 815,0 & 940,2 & 1180,3 & 1282,2 & 1547,7 \\
\hline 16 & CAG - 350 & 429,5 & 616,1 & 829,3 & 1053,4 & 1202,0 & 1245,4 \\
\hline 17 & CMTG - 350 & 367,2 & 668,4 & 770,1 & 815,9 & 1000,3 & 1071,5 \\
\hline 18 & PKG - 350 & 186,8 & 227,5 & 244,5 & 206,3 & 169,9 & 162,1 \\
\hline 19 & CMHG -350 & 361,6 & 493,7 & 685,5 & 776,5 & 789,7 & 924,0 \\
\hline 20 & CMBL - 350 & 342,5 & 504,7 & 666,3 & 866,9 & 1009,4 & 1078,7 \\
\hline 21 & CMCM - 350 & 395,2 & 446,1 & 512,9 & 745,4 & 828,5 & 966,7 \\
\hline 22 & SCAG - 400 & 726,7 & 1060,9 & 1115,4 & 1512,0 & 1569,0 & 1808,0 \\
\hline 23 & CAG - 400 & 607,0 & 691,1 & 851,2 & 1204,3 & 1277,2 & 1582,0 \\
\hline 24 & CMTG - 400 & 414,5 & 778,1 & 934,7 & 958,1 & 1045,0 & 1095,9 \\
\hline 25 & PKG - 400 & 204,6 & 236,0 & 271,3 & 254,7 & 201,0 & 183,2 \\
\hline 26 & CMHG -400 & 415,9 & 542,6 & 836,4 & 849,0 & 872,4 & 946,7 \\
\hline 27 & CMBL - 400 & 532,4 & 718,4 & 829,3 & 1059,3 & 1126,4 & 1283,8 \\
\hline 28 & CMCM -400 & 480,4 & 801,2 & 858,1 & 951,2 & 1191,2 & 1642,5 \\
\hline
\end{tabular}

Note: SCAG - Sandy clay, very soft at Cho Moi district, An Giang province $\left(a \mathrm{Q}_{2}{ }^{3}{ }_{2}\right)$

SCAG - Clay, very soft at Cho Moi district, An Giang province $\left(a \mathrm{Q}_{2}{ }^{3} 2\right)$

MTG - Clay mud at Cai Lay district, Tien Giang province $\left(\operatorname{am} \mathrm{Q}_{2}{ }^{2-3} 1\right)$ 
PKG - Peat at Go Quao district, Kien Giang province $\left(a b \mathrm{Q}_{2}{ }^{3}{ }_{1}\right)$

MBL - Clay mud at Dong Hai district, Bac Lieu province $\left(m b \mathrm{Q}_{2}{ }^{3}{ }_{2}\right)$

$\mathrm{MCL}$ - Clay mud at Cai Nuoc district, Ca Mau province $\left(m b \mathrm{Q}_{2}{ }^{3}{ }^{3}\right)$

$250,300,350,400-$ Cement contents $\left(\mathrm{kg} / \mathrm{m}^{3}\right.$

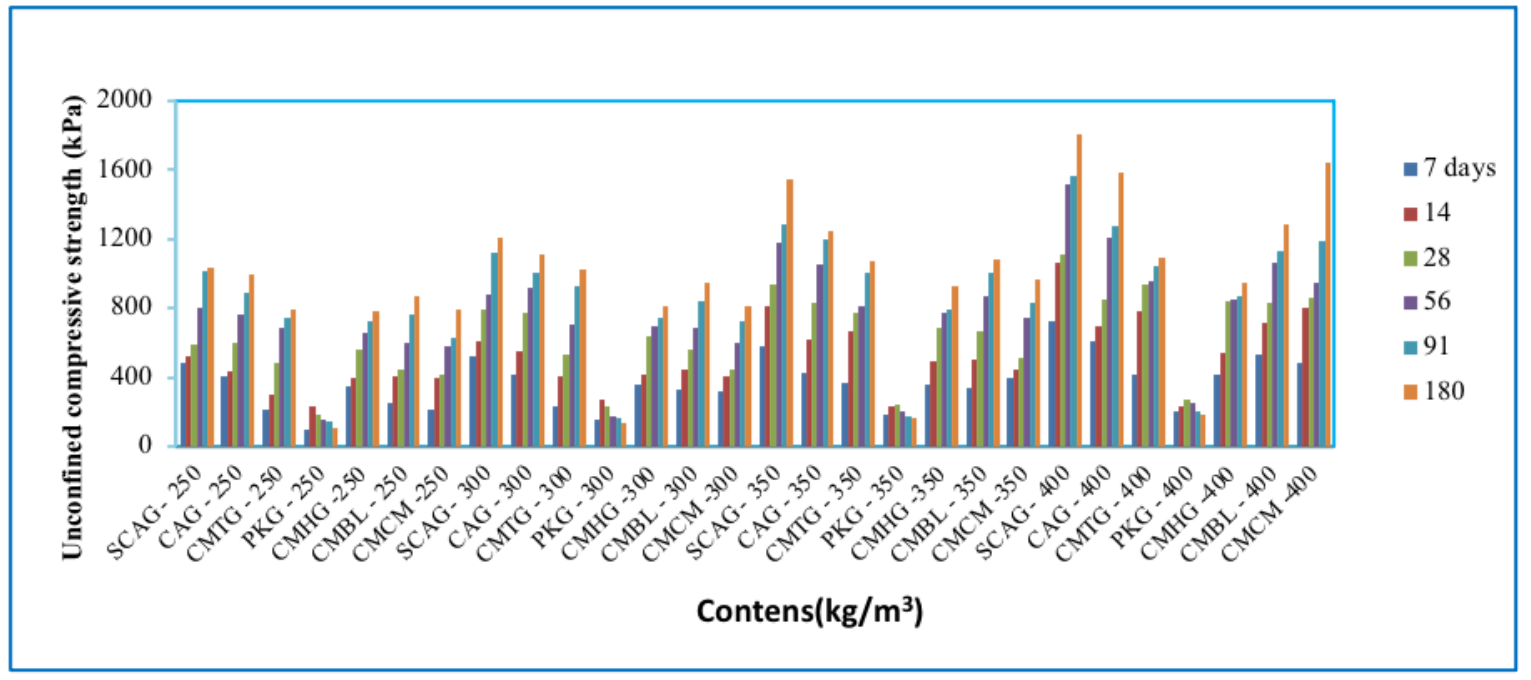

Fig. 3. Relationship between unconfined compressive strength with cement contents at different age days

The testing results show that:

Sandy clay mixed cement in An Giang is the greatest strength in all of the research contents and ages because the soil has a sand content, and the amount of $\mathrm{SiO}_{2}$ oxide is larger than other soils. Moreover, this soil type has montmorillonite, illite, and chlorite minerals that are smaller than soft soils clay in An Giang, clay mud in Tien Giang, Hau Giang, Bac Lieu, and Ca Mau. In addition, loss amount in the soil is the smallest, soil is not salty, a little content salt. Thus, factors such as grain composition, minerals, and salt contamination are affected the quality of the reinforced soil. Clays mud mixed cement in Tien Giang, Hau Giang, Bac Lieu, and Ca Mau have unconfined compressive strength are similar. However, clay mud in Ca Mau with $400 \mathrm{~kg} / \mathrm{m}^{3}$ content has strength as same as reinforcement of soft soil clay in An Giang.

Soft soil in An Giang, Hau Giang, Tien Giang, Bac Lieu and Ca Mau reinforced with cement has unconfined compressive strength that increases proportionally with curing time, while peat soil in Kien Giang has reinforced samples strength increased to 28 days of age than they were decreased (Fig.4). The reason is that in soil with high organic content, low $\mathrm{pH}$ reduces the hydration of cement. When soil is mixed with cement, according to the time of curing, the amount of organic matter continues to decompose, causing the $\mathrm{pH}$ to decrease, leading to the sample's strength loss after curing time is 28 days. On the other hand, the composition of the soil has a much higher Goethitle mineral content than the soil elsewhere and has contained the minerals Gypsum, Pyrite and Pyrophyllite.

In addition, peat soil in Kien Giang is bigger $\mathrm{SO}_{3}$ content than elsewhere soils (Table 4) and content $\mathrm{SO}_{4}$ is similar too (Table 5). These all factors affect the hydration of cement for peat soil. This research result is consistent with those of authors Yunus et al., (2013); Zhu et al, (2009); Koslanant et al., (2006); Harris et al., (2009). The strength of reinforced soil samples of peat in Kien Giang is much smaller than with soil samples in other places (Fig. 5). 

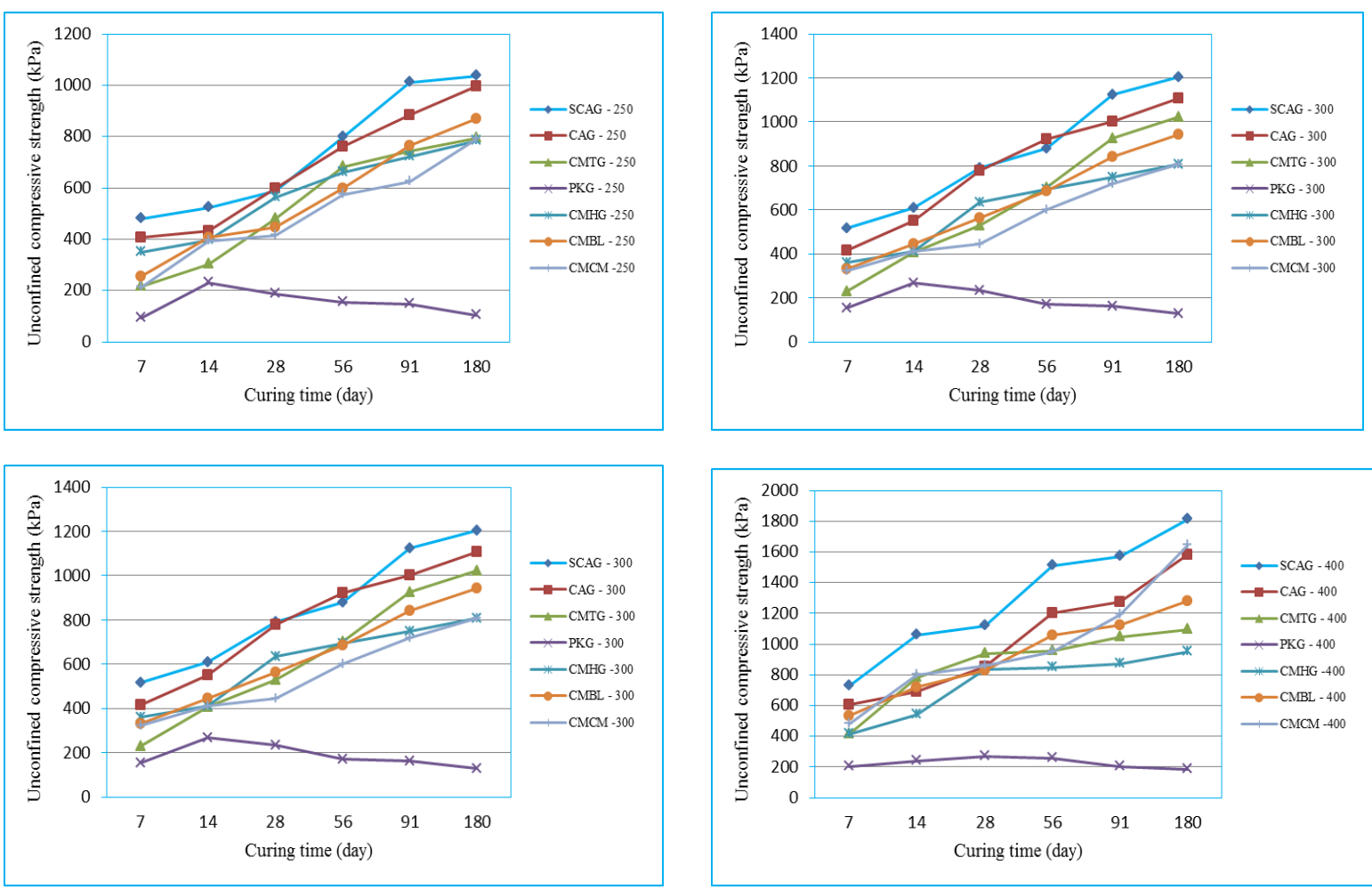

Fig. 4. Relationship between unconfined compressive strength of soils mixed cement with curing time

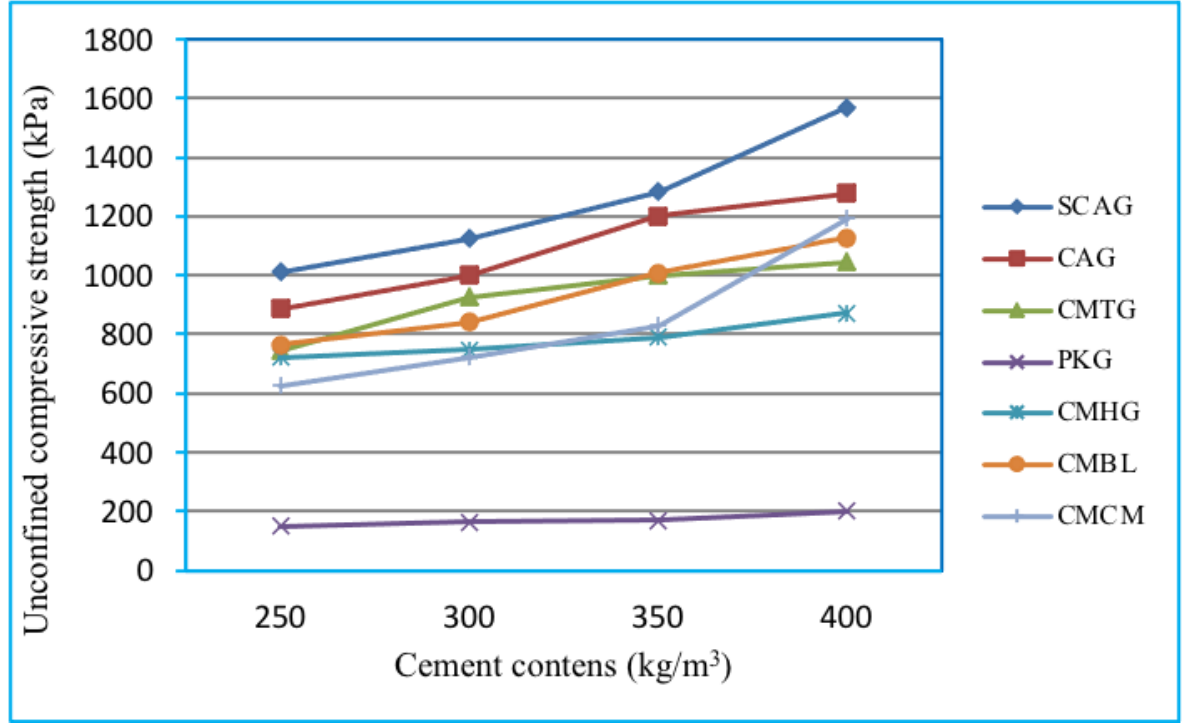

Fig. 5. Unconfined compressive strength of soils mixed cement with contents different at 91 days

\section{Conclusions}

- Soft soil clays $\left(\mathrm{amQ}_{2}\right)$ distributed in the provinces of An Giang, Tien Giang, Hau Giang, Kien Giang, Bac Lieu and Ca Mau are contaminated with easily soluble salts, mixed organic matter, existing mainly in the environment with $\mathrm{pH}<7$. Soft soils sandy clay, clay in An Giang, clay mud in Tien Giang are less acidic, not salty, and contaminated with Sulfate - Chloride salts. Clay mud in Hau Giang is less acidic, less salt, and contaminated with Chloride - Sulfate salts. Clay mud in Bac 
Lieu and Ca Mau are lots of salt and contaminated with Chloride salt. Peat soil in Kien Giang is strongly acidic, not salty, contaminated with salt in the form of Sulfate - Chloride.

- The results of soil improvement with cement show that sandy clay in An Giang is the greatest unconfined compressive strength, clay mud soils in Tien Giang, Hau Giang, Bac Lieu, and Ca Mau have similar strength, and peat soil in Kien Giang has a very small strength compared to soils in other places, this soil when improved with cement will not effective. With cement contents from 250 to $400 \mathrm{~kg} / \mathrm{m}^{3}$ at 28 days of curing age, the peat soil sample strength was only $31.5 \%$ to $43.5 \%$ (cement content $250 \mathrm{~kg} / \mathrm{m}^{3}$ ), $29.9 \%$ to $52.8 \%$ (cement content $300 \mathrm{~kg} / \mathrm{m}^{3}$ ), $26.0 \%$ to $47.7 \%$ (cement content $350 \mathrm{~kg} / \mathrm{m}^{3}$ ), and $29.9 \%$ to $52.8 \%$ (cement content $300 \mathrm{~kg} / \mathrm{m}^{3}$ ) compared to soft soils elsewhere.

- The curing process and experiment showed that the unconfined compressive strength of clay low organic soil in An Giang, Tien Giang, Hau Giang, Bac Lieu and Ca Mau increased with curing time, peat soil in Kien Giang has samples strength initially increased then they were decreased.

\section{Acknowledgements}

The author is very grateful to the reviewers, Editor in Chief Prof. Dr. Salih M. Awadh, the Secretary of Journal Mr. Samir R. Hijab, and the Technical Editors for their great efforts and valuable comments.

\section{References}

Anon, 1990. State-of-the-art report on soil-cement. American Concrete Institute Materials Journal, 87 (4), 395-417.

ASTMD 2166-00. Standard Test Method for Unconfined Compressive Strength of Cohesive Soil.

Awad, A.M. and Awadh, S.M., 2020. Reserve estimation of Late Miocene Injana claystone beds for portland cement and brick industry, Middle of Iraq. The Iraqi Geological Journal, 1-16.

Awadh, S.M. and Al-Owaidi, M.R., 2020. Application of triangles method for quantitative estimation of marl reserve in Euphrates formation, middle of Iraq. The Iraqi Geological Journal, 35-49.

Awadh, S.M. and Al-Owaidi, M.R., 2021. Designing Raw Mix for Manufacturing Portland Cement using Euphrates Formation Marl Instead of Clays. The Iraqi Geological Journal, 87-97.

Bell, F.G., 1976. The influence of the mineral content of clays on their stabilization with cement. Bulletin Association of Engineering Geologists, 13, 267-78.

Bell, F.G., 1993. Engineering Treatment of Soil, Published by E \& FN Spon.

BS EN ISO 17892-10:2018. Geotechnical investigation and testing - Laboratory testing of soil, Direct shear tests

Croft, J. B., 1968. The problem of predicting the suitability of soils for cementitious stabilization. Engineering Geology, 2, 397-424

DBJ08-40-94. Technical regulations on foundation treatment (translation), Shanghai standard, China.

Harris, P., Harvey, O., Sebesta, S., Chikyala, S. R., Puppala, A, Saride, S., 2009. Mitigating the effects of organics in stabilized soil. Technical Report No. 0-5540-1, Texas Transportation Institute, USA.

JGS, 0821-2000. Japanese Geotechnical Society Standard "Practice for Making and Curing Stabilized Soil Specimens Without Compaction"

Koslanant, S., Onitsuka, K., Negami, T., 2006. Influence of salt additive in lime stabilization of organic clay. Geotectonic English Journal, 37, 95-101.

Yunus, N. Z., Wanatowski, D., Stace, L. R., 2013. Lime stabilization of organic clay and the effects of humic acid content. Geotechnical Engineering Juornal of the SEAGS \& AGSSEA,44(1).

Sherwood, F.T., 1957. The stabilization with cement of weathered and sulphate-bearing clays. Geotechnique, 7, $179-91$

Toan Do Minh., 2013. Construction rockly soil and reinforcement method. Construction Publish of Vietnam, Ha Noi.

Zhu, W., Chiu, C. F., Zhang, C. L., Zeng, K. L., 2009. Effect of humic acid on the behavior of solidified dredged material. Candian Geological Journal, 46 (9), 1093-1099. 